\title{
Morphological characterization and molecular identification of Colletotrichum species associated to sweet persimmon anthracnose in Southern Brazil
}

\author{
Joel Andrioli ${ }^{1}$ iD Fernando Joel Scariot ${ }^{1^{*}}$ iD Ana Paula Longaray Delamare ${ }^{1}$ \\ Sergio Echeverrigaray ${ }^{1}$ iD
}

'Laboratório de Enologia e Microbiologia Aplicada, Instituto de Biotecnologia, Universidade de Caxias do Sul (UCS), 95070-560, Caxias do Sul, RS, Brasil. E-mail: ferjscariot@gmail.com. .Corresponding author.

\begin{abstract}
The highlands of Southern Brazil contribute with 40\% of Brazilian persimmon production. Although expanding, persimmon production faces major problems caused by anthracnose disease (black spot), including fruit rot and necrosis of leaves. Several Colletotrichum species (C. horii, C. gloeosporioides, among others) are implicated in persimmon anthracnose around the world. To identify Colletotrichum species associated with persimmon anthracnose in the highlands of Southern Brazil, 34 isolates were analyzed by ITS-rDNA partial region, GAPDH, and TUB2 partial gene sequences, morphological characteristics, and virulence on persimmon fruits and leaves. Data showed a high prevalence of C. horii (85.3\%), that associated with its high virulence on fruits and leaves, confirm a considerable degree of host preference. Moreover, other species C. aenigma, C. asianum, C. fructicola, and C. nymphaeae, were identified, but the last three ones exhibited low virulence on fruits and were not able to produce symptoms on leaves. As far as we know this is the first reference on C. asianum in persimmon. The present data may contribute to a better understanding of the etiology of anthracnose in sweet persimmon in Southern Brazil, and it will be useful for epidemiological studies and the development of disease management measures.
\end{abstract}

Key words: black spot, molecular identification, virulence.

Caracterização morfológica e identificação molecular de espécies de Colletotrichum associadas à antracnose de caqui doce no Sul do Brasil

RESUMO: As terras altas do sul do Brasil contribuem com 40\% da produção brasileira de caqui. Embora em expansão, a produção de caqui enfrenta grandes problemas causados pela antracnose (mancha preta), incluindo o apodrecimento dos frutos e necrose das folhas. Várias espécies de Colletotrichum (C. horii, C. gloeosporioides, entre outras) estão envolvidas com a antracnose do caqui em todo mundo. Para identificar espécies de Colletotrichum associadas à antracnose de caqui nas terras altas do sul do Brasil, 34 isolados foram analisados através da região parcial de ITS-rDNA e sequências parciais dos genes GAPDH e TUB2, características morfológicas e virulência em frutos e folhas de caqui. Os dados mostraram uma alta prevalência de C. horii (85,3\%), que associada à sua alta virulência em frutos e folhas, confirma um grau considerável de preferência pelo hospedeiro. Além disso, foram identificadas outras espécies C. aenigma, C. asianum, C. fructicola, e C. nymphaeae, mas as três últimas exibiram baixa virulência nos frutos e não foram capazes de produzir sintomas nas folhas. Até onde sabemos, esta é a primeira referência sobre C. asianum em caqui. Os presentes dados podem contribuir para uma melhor compreensão da etiologia da antracnose em caqui doce no sul do Brasil e isso pode ser útil para estudos epidemiológicos e para o desenvolvimento de medidas de controle da doença.

Palavras-chave: mancha preta, identificação molecular, virulência.

\section{INTRODUCTION}

Persimmon (Diospyros kaki L.) was introduced in Brazil by Japanese immigrants at the beginning of the 20th century, and its growing area has expanded considerably since the 1920 s. Nowadays, Brazil is the fourth world producer of persimmon with a planted area of 8,148 ha, and a production that reaches 157 thousand tons/year (IBGE, 2018). The highlands of Southern Brazil, which account for most of the Brazilian production, are part of a subtropical and temperate macroregion with altitude from 500 to $680 \mathrm{~m}$, a mean annual temperature of $17^{\circ} \mathrm{C}$, and a precipitation of $1908 \mathrm{~mm} /$ year.

The most prominent persimmon cultivars in Southern Brazil are Fuyu, Giombo, and Kyoto (FIORAVANÇO \& PAIVA, 2007). Although, growing at rates that reach $10 \%$ per year in Southern Brazil, 
persimmon culture faces a significant problem of increasing anthracnose damage in fruits leaves and branches, caused by Colletotrichum species, which are responsible for important losses in highly infected fields (MAY DE MIO et al., 2015; CARRARO et al., 2019).

Persimmon anthracnose in new twigs appears as small dark elliptic spots that enlarge during time and can coalesce. Leaves infected by Colletotrichum show small circular to elliptic purple to dark brown spots, and fruit anthracnose appears as small sunken and dark spots that progress to larger dark brown lesions $(>20 \mathrm{~mm})$ with grey center and orange conidia. Early fruit infections cause premature fruit drop. Moreover, the disease progress during ripening and after harvest, leading to important losses during storage, that can reach 50 to $90 \%$ (ZHANG, 2008; DAMM et al., 2010; PALOU et al., 2013).

The causal agent of persimmon anthracnose was first classified at the beginning of the 20th century as Gloesporium kaki, and later as Colletotrichum kaki (XIE et al., 2010). Based on molecular data and phylogenetic analysis, WEIR \& JOHNSTON (2010) reclassified this pathogen as Colletotrichum horii, one of the species of the Gloeosporioides complex. Since this report, $C$. horii has been confirmed as the most prevalent species associated with anthracnose in leaves, twigs and, fruit in Japan, China, Southeast Brazil, and Korea (YU et al., 2013; KWON et al., 2013; MAY DE MIO et al., 2015; HASSAN et al., 2018; JEON et al., 2017; ASANO \& HIRAYAMA, 2019; CARRARO et al., 2019). However, other Colletotrichum species have been reported causing anthracnose in persimmon leaves, twigs or, fruits, like $C$. acutatum in the USA (WILLIAMSON \& SUTTON, 2010), C. gloeosporioides in Spain (PALOU et al., 2013), C. karstii in China (WANG et al., 2016), C. kakivorum in Korea (LEE \& JUNG, 2018), C. fructicola, C. nymphaeae, C. meloni in Paraná, Brazil (CARRARO et al., 2019).

Aiming to expand the knowledge of anthracnose etiology in southern Brazil, the study characterized Colletotrichum isolates associated with the disease from the region based on the molecular, morphological, and pathogenic analysis and identified the species. Furthermore, the present survey can give subsidies for further epidemiological studies and disease management of this devastating disease.

\section{MATERIALS AND METHODS}

\section{Samples}

Persimmon fruits showing typical symptoms of anthracnose were collected from commercial orchards of the highlands of Southern Brazil (Table 1). Fruit skin tissues of approximately $5 \mathrm{~mm}$ in diameter, were collected, surface-sterilized with $1 \% \mathrm{NaClO}$ for $1 \mathrm{~min}$, washed twice with sterile distilled water, and partially dried with filter paper. The tissues were placed on PDA (potato-dextrose-agar) amended with gentamicin $(50 \mathrm{mg} / \mathrm{L})$ and cefotaxime $(100 \mathrm{mg} / \mathrm{L})$. The plates were incubated at $27^{\circ} \mathrm{C}$ for 4 days. Single-spore cultures were maintained in PDA slants and stored at $-80^{\circ} \mathrm{C}$ in cryotubes with $25 \%$ glycerol.

\section{DNA extraction and PCR amplifications}

DNA was extracted from fungal mycelia using the method proposed by TAPIA-TUSSELL et al. (2006). DNA was quantified by absorbance at 260 $\mathrm{nm}$, and the quality was estimated by $260 / 280$ ratio and agarose gel electrophoresis.

PCR amplification of the ITS1-5.8S-ITS2 rDNA, the GAPDH (glyceraldehyde-3-phosphate dehydrogenase) intron, and the TUB2 ( $\beta$-tubulin) gene of fungal isolates was performed using the primers described by WHITE et al. (1990), TEMPLETON et al. (1992), O’DONNELL \& CIGELNIK (1997), respectively. PCR amplifications $(25 \mu \mathrm{l})$ included a denaturation at $94^{\circ} \mathrm{C}$ for $60 \mathrm{~min}$, annealing at $55^{\circ} \mathrm{C}$ (ITS and TUB2) or $59^{\circ} \mathrm{C}(\mathrm{GADPH})$ for $1 \mathrm{~min}$, and extension at $72^{\circ} \mathrm{C}$ for $1.5 \mathrm{~min}$, with an initial denaturation of $5 \mathrm{~min}$ at $94^{\circ} \mathrm{C}$ and a final extension of $5 \mathrm{~min}$ at $72^{\circ} \mathrm{C}$. The amplifications were confirmed in $2 \%$ agarose gels with TBE (Tris-Borate-EDTA), stained with GelRed (Uniscience), and visualized under UV light.

\section{DNA sequencing of the amplicons}

Amplification products were enzymatically purified with EXOI/SAP (USB) following manufacture instructions. Purified amplicons (50-60 ng) were sequenced using Big Dye Terminator V.3.1 sequencing kit (Thermo) and analyzed with a 3500 Genetic Analyzer (Thermo). Data were collected by Data Collection software (Thermo).

\section{Molecular classification and phylogenetic analysis}

The DNA sequences were compared with those deposited in GenBank using the BLAST similarity test. Alignment of the ITS, GAPDH and, TUB2 sequences of the Colletotrichum isolates, references of Colletotrichum species, and Monilochaetes infuscans (outgroup) retrieved from NCBI database was performed with CLUSTAL X. Concatenated sequences were used for phylogenetic analysis using the maximum parsimony of MEGA 6.0 (TAMURA et al., 2013). 
Table 1 - Colletotrichum isolated from persimmon anthracnose in the state of Rio Grande do Sul - Brazil.

\begin{tabular}{|c|c|c|c|c|c|}
\hline Code & Geographical Origin & $\begin{array}{c}\text { Persimmon } \\
\text { variety }\end{array}$ & Code & Geographical Origin & $\begin{array}{c}\text { Persimmon } \\
\text { variety }\end{array}$ \\
\hline 19.1 & Alto Feliz & Giombo & DCFR6 & Farroupilha & Kyoto \\
\hline 19.18 & Alto Feliz & Giombo & DCFR7 & Farroupilha & Kyoto \\
\hline 19.19 & Alto Feliz & Giombo & DCFR8 & Farroupilha & Kyoto \\
\hline 19.21 & Alto Feliz & Giombo & DCU3 & Farroupilha & Fuyu \\
\hline 19.23 & Alto Feliz & Giombo & LMFC.19.3 & Alto Feliz & Giombo \\
\hline B5 & Caxias do Sul & Kyoto & LMFC.19.9c & Alto Feliz & Giombo \\
\hline B6 & Caxias do Sul & Kyoto & LMFC.19.17 & Alto Feliz & Giombo \\
\hline BFR6 & Farroupilha & Kyoto & LMFC.19.18 & Alto Feliz & Giombo \\
\hline $\mathrm{C} 2$ & Caxias do Sul & Kyoto & LMFC.19.19 & Alto Feliz & Giombo \\
\hline CCF1 & Alto Feliz & Giombo & LMFC. 19.20 & Alto Feliz & Giombo \\
\hline CF1 & Alto Feliz & Giombo & LMFC.19.21 & Alto Feliz & Giombo \\
\hline $\mathrm{CF} 4$ & Alto Feliz & Giombo & LMFC.19.22f & Alto Feliz & Giombo \\
\hline CF6 & Alto Feliz & Giombo & LMFC.19.23 & Alto Feliz & Giombo \\
\hline CRC3 & Caxias do Sul & Kyoto & PPFO.19.5 & Caxias do Sul & Kyoto \\
\hline CRF2 & Caxias do Sul & Kyoto & PPFR.19.21 & Caxias do Sul & Kyoto \\
\hline CRF3 & Caxias do Sul & Kyoto & PPFR.19.22 & Caxias do Sul & Kyoto \\
\hline DCFR5 & Farroupilha & Kyoto & $\mathrm{VF}$ & Vacaria & Kyoto \\
\hline
\end{tabular}

Clade stability was determined by 1,000 bootstrap replicates.

\section{Morphological characteristics of the species}

Radial mycelial growth was recorded daily by two perpendicular measures, for 7 days on PDA cultures at $28^{\circ} \mathrm{C}$ with $16 \mathrm{~h}$ photoperiod, initiated from $5 \mathrm{~mm}$ diameter mycelium plugs. Colony appearance and conidial production were evaluated on the seventh day. Conidia were recovered after 7 days on PDA plate by scraping with saline, followed by filtration. Conidial shape and size were microscopically evaluated at $\mathrm{x} 400$ magnification using a Nikon E200 microscope coupled with a CCD camera. Conidial appressoria were evaluated as proposed by LIU et al. (2016).

\section{Pathogenicity test}

The pathogenicity of representatives of the Colletotrichum species (five species and a total of 11 isolates) isolated from persimmon fruits was evaluated on leaves and fruits of Kyoto cultivar. Intact leaves were inoculated with $0.5 \mathrm{~cm}$ plugs of fungal mycelia obtained from 7 days cultures on PDA medium. The necrotic spots diameter was evaluated 7 days after incubation at $28^{\circ} \mathrm{C}$ on $99 \%$ humidity chambers. Persimmon fruits (without lesions) were inoculated with $10 \mu \mathrm{L}$ conidial suspensions $\left(1 \times 10^{6}\right.$ conidia/mL) freshly prepared and incubated on $99 \%$ humidity chambers for 7 days. The lesion diameters were determined using a digital calypter. In each assay, a total of eight repetitions (fruit or leaves) were utilized.

\section{Statistical analysis}

Results were analyzed statistically by analysis of variance (one-way ANOVA), and Tukey's test. The statistical analyses were performed using IBM-SPSS Statistics - version 22 software, and statistical significance was attributed to values of $\mathrm{P} \leq 0.05$.

\section{RESULTS AND DISCUSSION}

A total of 34 Colletotrichum were isolated from 36 persimmon fruits with symptoms of anthracnose collected on the highlands of Southern Brazil (Table 1). These isolates were all pathogenic to 
persimmon fruits and $60 \%$ of the leaves presented the anthracnose symptoms.

Isolates were evaluated by their ITS (514 bp), GAPDH (235 bp), and TUB2 (520 bp) sequences, and classified by comparison with reference sequences deposited on GenBank (Table 2). As can be observed in figure $1,97 \%$ of the isolates were included in the Gloeosporioides clade. Among these, 85.3\% (29/34)

Table 2 - Identification of Colletotrichum isolates and their GenBank accession code for ITS, GAPDH and TUB2 partial sequences.

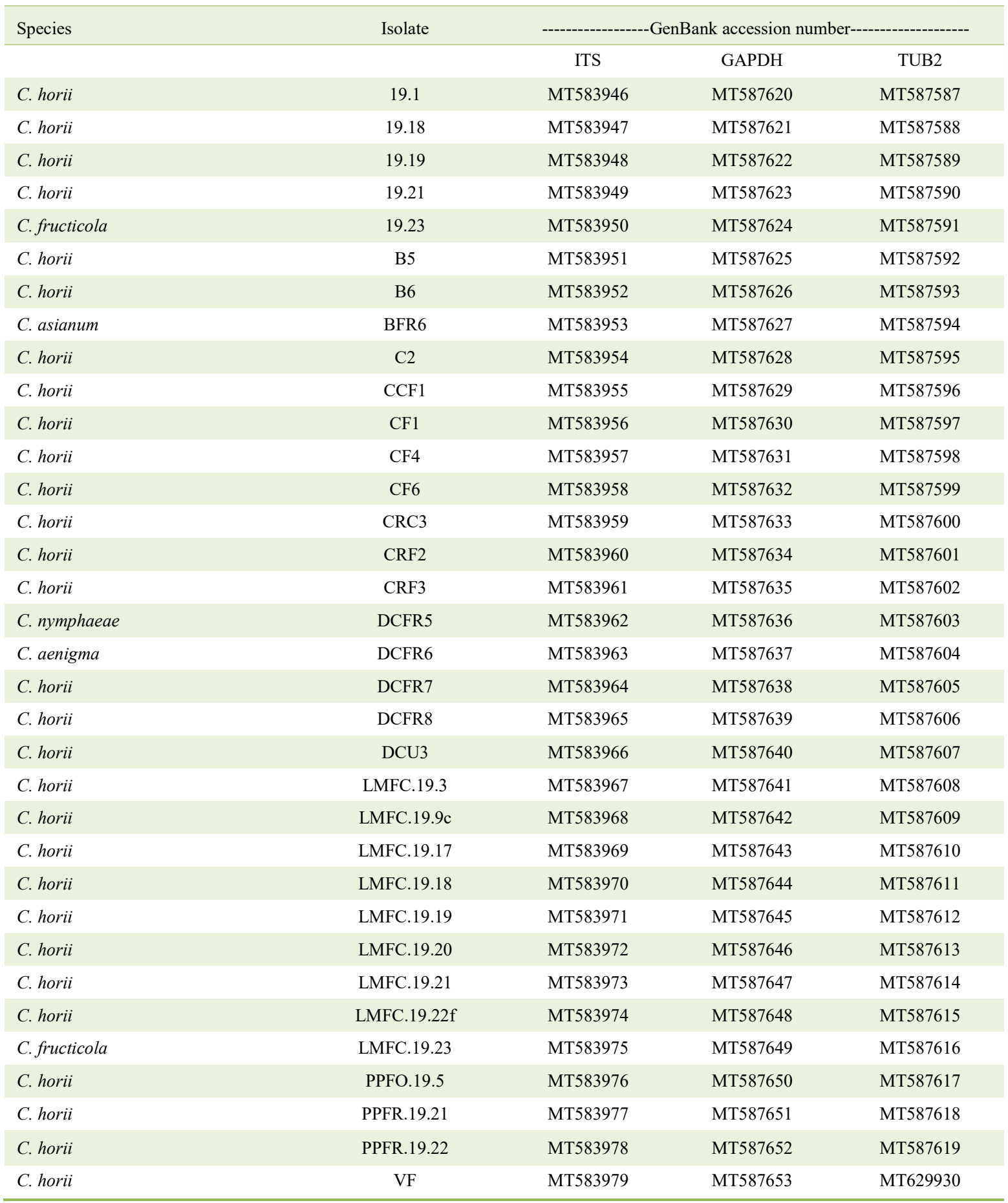




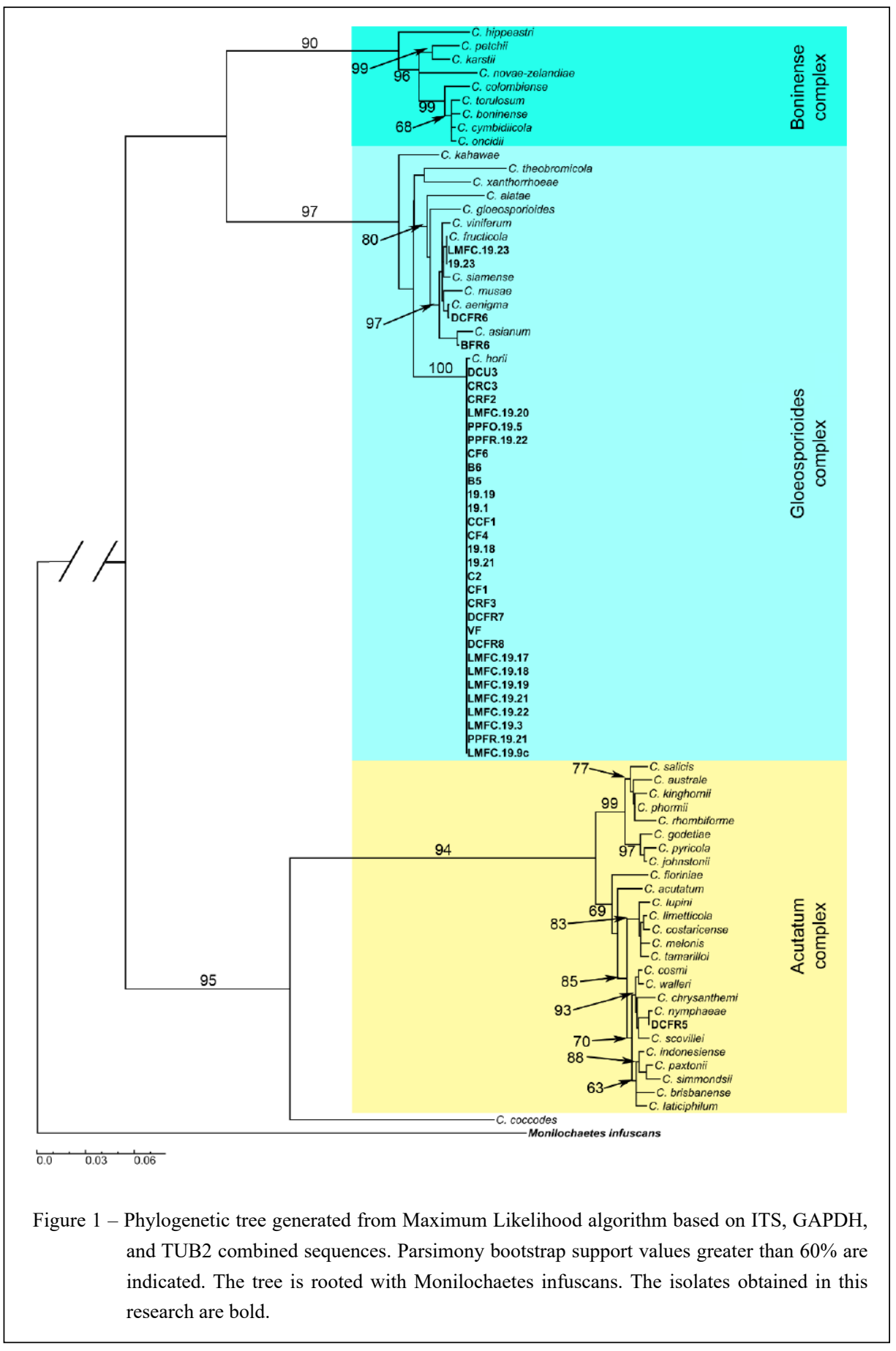

were highly related with Colletotrichum horii reference, $5.9 \%(2 / 34)$ were similar to $C$. fructicola, one isolate was closely related with $C$. asianum (2.9\%), a sister species of $C$. fructicola, and one was classified as $C$. aenigma $(2.9 \%)$. Just one isolate was classified as C. nymphaeae, a member of the Acutatum clade.

Colletotrichum species associated with anthracnose disease in persimmon varied depending on the classification methods. ZHANG et al. (2008), based on morphological characteristics classified persimmon anthracnose associated fungi as $C$. gloeosporioides, while WEIR \& JOHNSTON (2010) classified New Zealand isolates as a new species $C$. horii, within the Gloeosporioides clade. The present study, based on phylogenetic characterization, corroborated the high prevalence of $C$. horii associated with persimmon 
anthracnose, previously reported in both leaves and fruit diseases of persimmon in New Zealand, China, Korea, Japan, and Brazil (WEIR \& JOHNSTON, 2010; YU et al., 2013; KWON et al., 2013; MAY DE MIO et al., 2015; HASSAN et al., 2018; JEON et al., 2017; ASANO \& HIRAYAMA, 2019; CARRARO et al., 2019). Colletotrichum horii is highly host-specific (WEIS et al., 2012) which explains its high prevalence even in a region where crops such as apple and grapes, committed by $C$. fructicola and $C$. viniferum, are grown side by side with persimmon.

Although in a low-frequency, other species of Colletotrichum were isolated from persimmon fruits with anthracnose symptoms. $C$. fructicola has been reported as a causal agent of fruit anthracnose in apple (VELHO et al. 2015), grapes (ECHEVERRIGARAY et al., 2020), and other crop fruits in Brazil, and was first reported in persimmon in Parana State (Southern Brazil) by CARRARO et al. (2019), and C. aenigma was previously associated to sweet persimmon anthracnose in Korea (HASSAN et al., 2018), and grape ripe-rot disease in Southern Brazil (ECHEVERRIGARAY et al., 2020). Moreover, C. asianum is associated with anthracnose in coffee (PRIHASTUTI et al., 2009) and mango (SHARMA et al., 2015, VITALE et al., 2020), but this is the first report of this species on persimmon.

Just one isolate $(2.9 \%)$ was classified as $C$. nymphaeae (Acutatum clade), and references to this species associated with persimmon anthracnose were cited in Korea (HASSAN et al., 2018) and Brazil (CARRARO et al., 2019).

Six representative isolates of $C$. horii and all the isolates of the other species identified by sequencing were further evaluated for their growing and morphological characteristics. As can be observed in figure 2 and table 3, the Gloeosporioides clade species (C. horii, C. fructicola, C. aenigma,

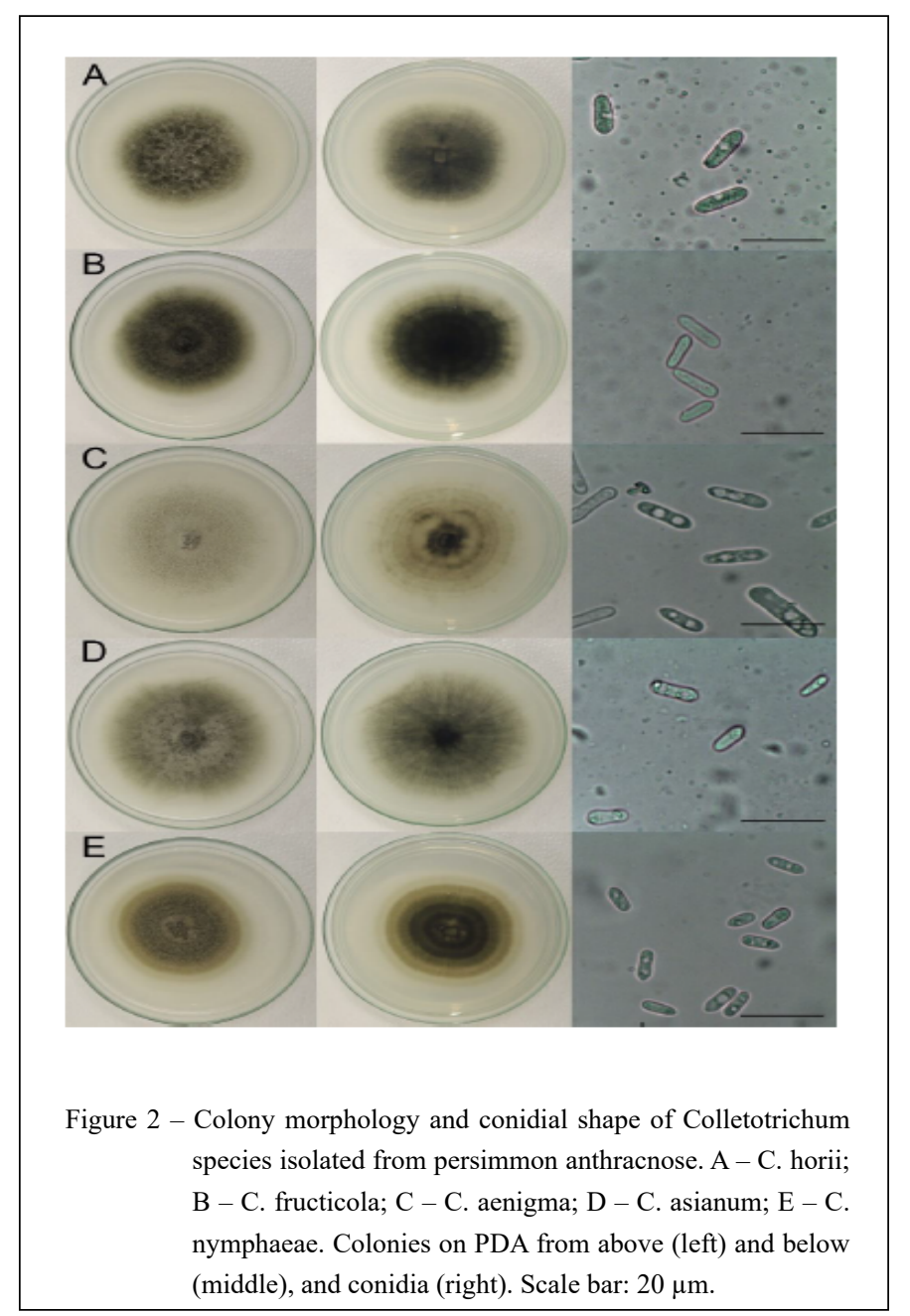

Ciência Rural, v.51, n.9, 2021. 
Table 3 - Morphological characteristics (colony, conidia, and appressoria morphology) of Colletotrichum species Isolated from persimmon anthracnose in Southern Brazil.

\begin{tabular}{|c|c|c|c|c|c|}
\hline \multirow[b]{2}{*}{ Species } & \multicolumn{5}{|c|}{--1-- } \\
\hline & C. horii & C. fructicola & C. aenigma & C. asianum & C. nymphaeae \\
\hline $\mathrm{N}^{\circ}$ Isolates evaluated & 6 & 2 & 1 & 1 & 1 \\
\hline Colony morphology & $\begin{array}{l}\text { grey-green, } \\
\text { reverse light grey } \\
\text { with darker grey } \\
\text { sectors }\end{array}$ & $\begin{array}{l}\text { pale grey with } \\
\text { concentric grey } \\
\text { sectors, reverse } \\
\text { light grey with } \\
\text { concentric dark } \\
\text { grey sectors }\end{array}$ & $\begin{array}{l}\text { White to pale } \\
\text { grey, reverse } \\
\text { white with } \\
\text { concentric pale } \\
\text { grey sectors }\end{array}$ & $\begin{array}{l}\text { dark green, } \\
\text { reverse pale grey } \\
\text { with concentric } \\
\text { dark grey sectors }\end{array}$ & $\begin{array}{l}\text { light grey/green, } \\
\text { reverse white with } \\
\text { concentric grey/green } \\
\text { sectors }\end{array}$ \\
\hline Growth rate (mm/day) & $9.8 \pm 1.3 \mathrm{bc}$ & $10.5 \pm 0.5 b$ & $10.0 \pm 0.5 b$ & $11.3 \pm 0.1 \mathrm{a}$ & $9.3 \pm 0.2 \mathrm{c}$ \\
\hline Conidia length $(\mu \mathrm{m})$ & $18.1 \pm 2.2$ & $13.9 \pm 1.5$ & $15.1 \pm 2.4$ & $14.9 \pm 1.5$ & $10.2 \pm 1.4$ \\
\hline Conidia width $(\mu \mathrm{m})$ & $5.5 \pm 0.4$ & $5.1 \pm 0.8$ & $5.2 \pm 0.7$ & $4.8 \pm 0.6$ & $4.6 \pm 0.7$ \\
\hline Conidia shape & Cylindrical & Cylindrical & Cylindrical & Cylindrical & Cylindrical \\
\hline Conidial appressoria & $\begin{array}{l}\text { Dark brown, ovoid } \\
\text { to cylindrical }\end{array}$ & $\begin{array}{l}\text { Dark brown, } \\
\text { ovoid or slightly } \\
\text { irregular }\end{array}$ & $\begin{array}{l}\text { Very few, dark } \\
\text { brown, and } \\
\text { ovoids }\end{array}$ & $\begin{array}{l}\text { Dark brown, } \\
\text { ovoid }\end{array}$ & $\begin{array}{l}\text { Light brown, elliptical } \\
\text { or slightly irregular }\end{array}$ \\
\hline
\end{tabular}

* Different letters in the same line correspond to significant different mean values at $\mathrm{P} \leq 0.05$ by Tukey test.

and $C$. asianum) showed similar growing culture patterns on BDA medium, but the $C$. nymphaeae isolate exhibited a lower growth rate than the species of Gloeosporioides clade. Although, considered an important character of fungi, the growth rate is not directly related to fungal pathogenicity. As can be observed in figure 2 and table $3, C$. horii, and $C$. asianum showed similar growth color and behavior defined as grey-green, with a reverse light grey with darker grey sectors. Conversely, $C$. aenigma had white to pale grey colony with concentric pale grey sectors, and C. nymphaeae showed light grey/green colonies with reverse white with concentric grey/ green sectors. The morphological characteristics of the persimmon isolates obtained in this research are similar to those described for these species (WEIS et al., 2012; DAMM et al., 2012).

All isolates produce hyaline conidia with a classical cylindrical shape with broadly rounded ends (Figure 2 and Table 3). However, as expected, species classified within the Gloeosporioides clade (C. horii, C. fructicola, C. aenigma, and C. asianum) showed longer and wider conidia than those of the C. nymphaeae isolate (Acutatum clade). Moreover, among the Gloeosporioides clade species, the conidia of $C$. asianum was somehow shorter than the other species of the clade, confirming the data published by WEIR et al. (2012).

Conidial appressoria were produced by all the isolates and species but were particularly scarce in the C. aenigma isolate. All of them exhibited the characteristic light brown to brown color determined by the accumulation of melanin pigments (KUBO \& FURUZAWA, 1991). Conidial appressoria showed a similar size $(14.1 \pm 1.3 \times 7.3$ $\pm 1.4 \mu \mathrm{m})$ and did not differ significantly within and among species.

Pathogenicity tests on fruits and leaves of persimmon (vr. Kyoto) showed that all the species were able to infect fruits (Figure 3), and $C$. horii isolates cause larger lesions than the other species, indicating that the aggressiveness to persimmon varied among species, and can be responsible for the high prevalence of $C$. horii in anthracnose symptomatic fruits. Moreover, the six isolates of $C$. horii evaluated developed larger necrotic spots on persimmon leaves, reinforcing the high pathogenicity and host-specificity of $C$. horii on persimmon (XIE et al., 2010; MAY $\mathrm{DE} \mathrm{MIO}$ et al., 2015). Moreover, just one of the two isolates of $C$. fructicola, and none of the isolates of $C$. aenigma, $C$. asianum, and C. nymphaeae developed necrotic regions on persimmon leaves. 


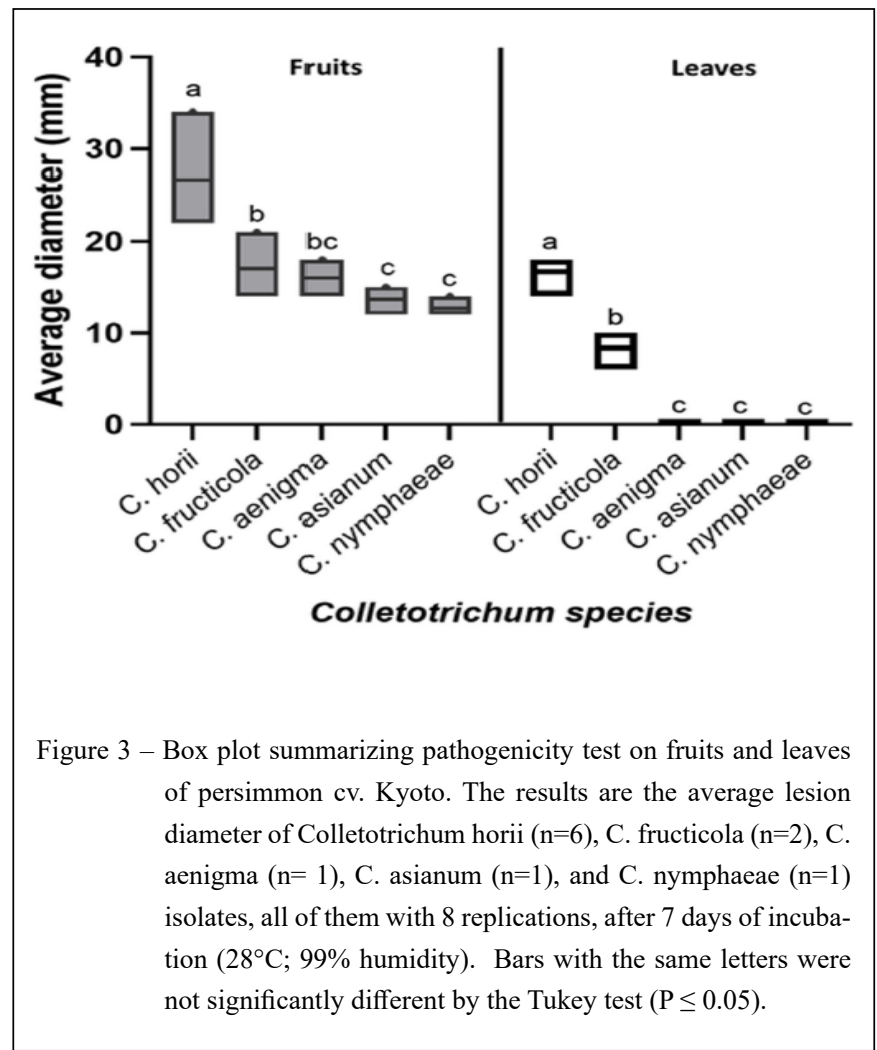

In conclusion, based on morphological data and molecular classification, five species of Colletotrichum were identified as causal agents of anthracnose in persimmon in the Southern Brazil region. These species belong to two different complexes (gloeosporioides and acutatum), with a high prevalence of $C$. horii. Although, all the species were able to infect and develop typical anthracnose symptoms in fruits of persimmon of Kyoto cultivar, the $C$. horii isolates were the most virulent, and together with $C$. fructicola were the only species that infected the persimmon leaves.

\section{ACKNOWLEDGEMENTS}

This study was supported by the Brazilian National Council for Scientific and Technological Development CNPq (Process: 304906/2017-4), and the Coordenação de Aperfeiçoamento de Pessoal de Nível Superior - CAPES (Finance Code 001)

\section{DECLARATION OF CONFLICT OF INTEREST}

The authors declare no conflict of interest. The founding sponsors had no role in the design of the study; in the collection, analyses, or interpretation of data; in the writing of the manuscript, and in the decision to publish the results.

\section{AUTHORS' CONTRIBUTIONS}

All authors contributed equally for the conception and writing of the manuscript. All authors critically revised the manuscript and approved of the final version.

\section{REFERENCES}

ASANO, S., HIRAYAMA, Y. Seasonal effect on infection with Colletotrichum horii causing anthracnose in persimmon twigs and the relation between its prevalence in twigs and occurrence in fruit. Annual Report of The Kansai Plant Protection Society, v.61, p.75-78, 2019. Available from: <https://www.jstage.jst.go.jp/ article/kapps/61/0/61_75/_article/-char/ja/>. Accessed: jul, 2020. doi: $10.4165 /$ kapps.61.75.

CARRARO, T.A. et al. First Report of Colletotrichum fructicola, $C$. nymphaeae, and C. melonis Causing Persimmon Anthracnose in Brazil. Plant Disease, v. 103, n. 10, p. 2692-2692, 2019. Available from: $<$ https://apsjournals.apsnet.org/doi/full/10.1094/PDIS-12-18-2241PDN $>$. Accessed: jul, 2020. doi: 10.1094/PDIS-12-18-2241-PDN.

DAMM, U. et al. Colletotrichum: species, ecology and interactions. IMA fungus, v. 1, n. 2, p. 161-165, 2010. Available from: <https:/link.springer.com/article/10.5598/ imafungus.2010.01.02.08>. Accessed: jul: 2020. doi: 10.5598/ imafungus.2010.01.02.08.

DAMM, U. et al. The Colletotrichum acutatum species complex. Studies in mycology, v. 73, p. 37-113, 2012. Available from: <https:// www.sciencedirect.com/science/article/pii/S0166061614600762>. Accessed: jul, 2020. doi: 10.3114/sim0010. 
ECHEVERRIGARAY, S. et al. Colletotrichum species causing grape ripe rot disease in Vitis labrusca and $V$. vinifera varieties in the highlands of Southern Brazil. Plant Pathology. In print. Available from: <https:/bsppjournals.onlinelibrary.wiley.com/ doi/abs/10.1111/ppa.13240>. Accessed: jul, 2020. doi: 10.1111/ ppa. 13240

FIORAVANÇO, J.C.; PAIVA, M.C. Cultura do caquizeiro no Brasil e no Rio Grande do Sul. Situação, potencialidade e entraves para o seu desenvolvimento. Informações Econômicas, v. 37, n. 4, 2007. Available from: <http://www.iea.sp.gov.br/ftpiea/ie/2007/ pag\%2043-51.pdf>. Accessed: jul, 2020.

HASSAN, O. et al. Molecular and morphological characterization of Colletotrichum species in the Colletotrichum gloeosporioides complex associated with persimmon anthracnose in South Korea. Plant Disease, v. 102, n. 5, p. 1015-1024, 2018. Available from: $\quad<$ https://apsjournals.apsnet.org/doi/full/10.1094/PDIS-1017-1564-RE $>$. Accessed: jul, 2020. doi: 10.1094/PDIS-10-171564-RE.

IBGE, Instituto Brasileiro de Geografia e Estatística. Produção Agrícola Municipal. 2018. Available from: <http://www.sidra. ibge.gov.br>. Accessed: jul, 2020.

JEON, J. Y. et al. Anthracnose of persimmon (Diospyros kaki) caused by Colletotrichum horii in Sangju, Korea. Plant Disease, v. 101, n. 6, p. 1035-1035, 2017. Available from: <https://apsjournals. apsnet.org/doi/full/10.1094/PDIS-01-17-0085-PDN>. Accessed: jul, 2020. doi: 10.1094/PDIS-01-17-0085-PDN

KUBO, Y.; FURUZAWA, I. 1991. Melanin biosynthesis: Prerequisite for successful invasion of the plant host by appressoria of Colletotrichum and Pyricularia. In: The Fungal Spore and Disease Initiation in Plants and Animals. Plenum, New York, 1991, pp. 205-217.

KWON, J. et al. Anthracnose caused by Colletotrichum horii on sweet persimmon in Korea: Dissemination of conidia and disease development. Journal of Phytopathology, v. 161, n. 7-8, p. 497-502, 2013. Available from: <https://onlinelibrary.wiley.com/ doi/full/10.1111/jph.12096>. Accessed: jul, 2020. doi: 10.1111/ jph. 12096

LEE, S.; JUNG, H. Colletotrichum kakivorum sp. nov., a new leaf spot pathogen of persimmon in Korea. Mycological Progress, v. 17, n. 10 , p. 1113-1121, 2018. Available from: <https://link. springer.com/article/10.1007/s11557-018-1424-3>. Accessed: jul, 2020. doi: $10.1007 / \mathrm{s} 11557-018-1424-3$

LIU, F. et al. Molecular and phenotypic characterization of Colletotrichum species associated with anthracnose disease in peppers from Sichuan Province, China. Scientific Reports, v. 6, p. 32761, 2016. Available from: < https://www.nature.com/articles/ srep32761/>. Accessed: jul 2020. doi: 10.1038/srep32761.

MAY DE MIO, L.L. et al. Twig blight and defoliation caused by Colletotrichum horii in persimmons in Brazil. Revista Brasileira de Fruticultura, v. 37, n. 1, p. 256-260, 2015. Available from: <https://www.scielo.br/scielo.php?pid=S010029452015000100256\&script $=$ sci arttext $>$. Accessed: jul, 2020. doi: 10.1590/0100-2945-044/14.

O’DONNELL, K.; CIGELNIK, E. Two divergent intragenomic rDNA ITS2 types within a monophyletic lineage of the fungus Fusarium are nonorthologous. Molecular phylogenetics and evolution, v. 7, n. 1, p. 103-116, 1997. Available from: $<$ https://www. sciencedirect.com/science/article/abs/pii/S1055790396903760>. Accessed: jul, 2020. doi: 10.1006/mpev.1996.0376.

PALOU, L. et al. Postharvest anthracnose of persimmon fruit caused by Colletotrichum gloeosporioides first reported in Spain. Plant Disease, v. 97, n. 5, p. 691-691, 2013. Available from: <https:// apsjournals.apsnet.org/doi/abs/10.1094/PDIS-11-12-1044-PDN>. Accessed: jul, 2020. doi: 10.1094/PDIS-11-12-1044-PDN.

PRIHASTUTI, H. et al. Characterization of Colletotrichum species associated with coffee berries in northern Thailand. Fungal Diversity, v. 39, n. 1, p. 89-109, 2009. Available from: <https:// www.fungaldiversity.org/fdp/sfdp/FD39-4-E $>$ Accessed: jul, 2020.

SHARMA, G. et al. First report of Colletotrichum asianum causing mango anthracnose in South Africa. Plant Disease, v. 99, n. 5, p. 725-725, 2015. Available from: <https://apsjournals.apsnet.org/ doi/full/10.1094/PDIS-08-13-0837-PDN>. Accessed: jul, 2020. doi: 10.1094/PDIS-08-13-0837-PDN.

TAPIA-TUSSELL, R. et al. A rapid and simple method for DNA extraction from yeasts and fungi isolated from Agave fourcroydes. Molecular Biotechnology, v. 33, n. 1, p. 67-70, 2006. Available from: <https://link.springer.com/article/10.1385/ MB:33:1:67>. Accessed: jul, 2020. doi: 10.1385/MB:33:1:67.

TEMPLETON, M.D. et al. Cloning and molecular characterization of the glyceraldehyde-3-phosphate dehydrogenase-encoding gene and cDNA from the plant pathogenic fungus Glomerella cingulata. Gene, v. 122, n. 1, p. 225-230, 1992. Available from: $\quad<$ https://www.sciencedirect.com/science/article/abs/ pii/037811199290055T > . Accessed: jul, 2020. doi: 10.1016/03781119(92)90055-T.

TAMURA, K. et al. MEGA6: molecular evolutionary genetics analysis version 6.0. Molecular biology and evolution, v. 30, n. 12, p. 2725-2729, 2013. Available from: <https://academic.oup. com/mbe/article/30/12/2725/1017851>. Accessed: jul, 2020. doi: $10.1093 / \mathrm{molbev} / \mathrm{mst} 197$.

VELHO, A.C. et al. New insights into the characterization of Colletotrichum species associated with apple diseases in southern Brazil and Uruguay. Fungal Biology, v. 119, n. 4, p. 229-244, 2015. Available from: <https://www.sciencedirect.com/science/article/ pii/S1878614614001858>. Accessed: jul, 2020. doi: 10.1016/j. funbio.2014.12.009

VITALE, A. et al. Cultivar Resistance against Colletotrichum asianum in the World Collection of Mango Germplasm in Southeastern Brazil. Plants, v. 9, n. 2, p. 182, 2020. Available from: <https://www.mdpi.com/2223-7747/9/2/182>. Accessed: jul, 2020. doi: 10.3390/plants9020182.

WANG, J. et al. First report of Colletotrichum karstii causing anthracnose on persimmon leaves in China. Plant Disease, v. 100, n. 2, p. 532-532, 2016. Available from: <https://apsjournals.apsnet. org/doi/full/10.1094/PDIS-07-15-0787-PDN>. Accessed: jul, 2020. doi: 10.1094/PDIS-07-15-0787-PDN.

WEIR, B.S.; JOHNSTON, P.R. Characterization and neotypification of Gloeosporium kaki Hori as Colletotrichum horii nom. nov. Mycotaxon, v. 111, n. 1, p. 209-219, 2010. Available from: $\quad<$ https://www.ingentaconnect.com/contentone/mtax/ $\mathrm{mt} / 2010 / 00000111 / 00000001 /$ art00030\#>. Accessed: jul, 2020. doi: $10.5248 / 111.209$ 
WEIR, B. S.; JOHNSTON, P. R.; DAMM, U. The Colletotrichum gloeosporioides species complex. Studies in mycology, v. 73, p. 115-180, 2012. Available from: <https:/www.sciencedirect.com/ science/article/pii/S0166061614600774> Accessed: jul, 2020. doi: $10.3114 / \operatorname{sim} 0011$.

WHITE T.J. et al. 1990. Amplification and direct sequencing of fungal ribosomal RNA genes for phylogenetics. In: PCR protocols: a guide to methods and applications. Academic Press, San Diego, 315-322.

WILLIAMSON, S.M.; SUTTON, T.B. First report of anthracnose caused by Colletotrichum acutatum on persimmon fruit in the United States. Plant Disease, v. 94, n. 5, p. 634-634, 2010. Available from: <https://apsjournals.apsnet.org/doi/abs/10.1094/ PDIS-94-5-0634A > Accessed: jul. 2020. doi: 10.1094/PDIS-945-0634A.
XIE, L. et al. Biology of Colletotrichum horii, the causal agent of persimmon anthracnose. Mycology, v. 1, n. 4, p. 242-253, 2010. Available from: <https://www.tandfonline.com/doi/ful 1/10.1080/21501203.2010.526644> Accessed: jul. 2020. doi: $10.1080 / 21501203.2010 .526644$.

YU, X. Isolation and identification of pathogen of 'Jirou' persimmon anthracnose disease from Yishui, Shandong, China. Acta Horticulturae, v.996, p.271-276, 2013. Available from: <https://www.actahort.org/books/996/996_37.htm> Accessed: jul, 2020. doi: 10.17660/ActaHortic.2013.996.37.

ZHANG, J. Anthracnose of persimmon caused by Colletotrichum gloeosporioides in China. Asian and Australasian Journal of Plant Science and Biotechnology, v. 2, n. 2, p. 50-54, 2008. Available from: $<$ http://www.globalsciencebooks.info/Online/GSBOnline/images/0812/ AAJPSB_2(1\&2)/AAJPSB_2(2)50-54o.pdf $>$ Accessed: jul, 2020. 